\title{
Barnabas: A leadership model for the Nigerian society
}

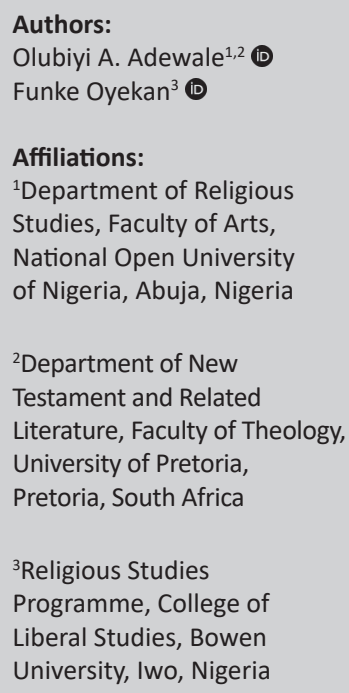

Research Project Registration: Project Leader: E. van Eck (D) Project Number: 2400030

\section{Description:}

This study is part of the research project 'Africa Platform for NT Scholars', directed by Prof. Dr Ernest van Eck, Department of New Testament Studies and Related Literature, Faculty of Theology and Religion, University of Pretoria.

Corresponding author: Olubiyi Adewale, bbearers@yahoo.com

\section{Dates:}

Received: 19 Apr. 2021 Accepted: 01 June 2021 Published: 13 Sept. 2021

How to cite this article: Adewale, O.A. \& Oyekan, F., 2021, 'Barnabas: A leadership model for the Nigerian society', HTS Teologiese Studies/Theological Studies 77(1), a6760. https://doi. org/10.4102/hts.v77i1.6760

\section{Read online:}

It has usually been accepted that the success of any organisation or nation depends on the ability of its leader to govern and manage its affairs. The failure of most developing countries, especially Nigeria, has often been blamed on bad leadership. Most Nigerians are of the opinion that the leadership problem in Nigeria has been the major impediment in the nation's development. Most people also agree that corruption and bad governance, which are prevalent in Nigeria today, are the results of leadership failure. The consensus among scholars, critics and observers of the Nigerian state is that the current situation of the nation is the result of lack of good and purposeful leadership. It is because of leadership failure in the country that Nigerians today clamor for good and purposeful leadership. This paper is a contribution to the search for the long-awaited leader. This paper examines Barnabas' character using the narrative method.

Contribution: This article reveals that Barnabas was a bridge-builder, team player, nondiscriminatory and not power or position drunk and these are the traits that should be used as a model in selecting or electing leaders within ecclesiastical and secular circles.

Keywords: New Testament; Acts of the Apostle; Barnabas; characterisation; leadership.

\section{Introduction}

Before proceeding on this study, it is necessary to explore the function of characterisation in narrative texts. It has been said that characterisation makes the plot in a narrative come to life. Character is also the axis of a serious story. Every story has at least two main elements: events and characters (Rimmon-Kenan 2002:3, 6). Others include time, space and narrative (ideological) perspective. Out of these two main elements, Farelly (2010:7) opined that characterisation is the most interesting element in any story. It is also important to note (Bennema 2014):

[V]arious biblical authors use the characters in the story to communicate their point of view to the readers, and in so doing recommend some characters to be emulated and others to be avoided. (p. 1)

It could be deduced from this that the study of characters in the biblical narrative could lead to the determination of what to emulate and what to avoid. This informs my choice of Barnabas, a character that has been seriously neglected in the study of biblical narratives (Stenschke 2010) but yet reveals much needed qualities of leadership.

\section{Characterisation in Acts: A brief survey}

Gowler (1991) carried out a pioneering work on character study in Luke-Acts wherein he devoted a long section on character using both the modern literary theory and ancient narratives. He affirmed that character and plot are interdependent, and made use of direct and indirect presentation of characters in the text. Darr (1992) agreed that character and plot are interdependent. He asserts that the development of a narrative character is cumulative as readers proceed along the text continuum. Character is related through showing or telling, and characters are reconstructed by a reader using intratextual information (Darr 1992). Expanding his assertion that readers create a character, Darr (1993) opined that the seamlessness of the text (i.e. the presence of gaps, indeterminacies, tensions, inconsistencies and ambiguities) makes the reader to seek a consistent, coherent narrative by piecing textual information together. In the same vein, for Shepherd (1994) the character is both in the text and in front of the text, that is, a character is generated by the text and constructed by the reader who fills in the gaps in the text. Thompson (2006) argued that the writer guides the reader through the narrative towards a judgement and response, concluding that the reader and not just the text that defines the character. He concludes that 'the reader must actively make judgment and decisions about those characters from the

Copyright: (C) 2021. The Authors. Licensee: AOSIS. This work is licensed under the Creative Commons Attribution License. Note: Special Collection: Africa Platform for NT Scholars, sub-edited by Ernest van Eck (University of Pretoria). 
information that the text provides' (Thompson 2006:20). Cheng (2011) holds that in Acts, characterisation is more of showing than telling in matters of presentation.

From the above survey, the various approaches taken by the scholars notwithstanding, certain principles are resonant, namely:

1. The writer presents characters, through the text, mostly from the writer's viewpoint.

2. Readers reconstruct characters from the text.

3. Characters are presented through direct characterisation (telling) and indirect characterisation (showing).

Consequently, the direct and the indirect characterisation would be used in this article.

\section{Barnabas: Previous works}

Most works on Barnabas have focused on the Epistle of Barnabas supposedly written by him or his work with Paul as a missionary where he had always been viewed as the inferior one. Most of the studies did not focus on a character study of Barnabas. The closest work that deals exhaustively with Barnabas is that of Murphy (2010), who has proven to be one of the best on the character study of Barnabas. Structured on his belief that events and characters make up the narrative, this article presents the passages where Barnabas' person was thrown up as 'events' and then creates a subsection on it as 'character'. The following are his conclusions on the character of Barnabas:

1. Barnabas is depicted as an intermediary and a relational bridge-builder.

2. He is portrayed as an admired representative of the church in both Jerusalem and Antioch.

This surface characterisation of Barnabas by Murphy (2010) is understandable because going by the topic of the study, it was not supposed to be a pure characterisation; however, it is designed to use the character presentation as a means of deciphering the role of Barnabas in Acts. This study, however, aims at looking at the character presentation of Barnabas in its entirety with focus on those qualities that makes him a model for leadership. In this study, Barnabas' character development, as presented in Acts, would be presented in the following sections:

\section{Barnabas: The entrance of a leader (Acts 4:36-37)}

In Acts 4:36-37, Luke uses direct characterisation in presenting Barnabas. This is significant because the readers cannot construct the information available here. Thus, Luke had no choice but to tell us directly what he wants us to know.

Barnabas was introduced to the readers for the first time in these two verses. Within the context of Acts, so far, this has been the first time Barnabas would be mentioned. Firstly, this implies that he was not part of the Jesus movement from the beginning. Secondly, he must have been part of the 5000 souls who have been added to the disciples after Jesus' ascension. This was confirmed by verse 36 , which indicated that he was a Cyprian. This means Barnabas was a Diaspora Jew or a Hellenist. Thirdly, we also know that his real name was Joseph, and that Barnabas was a nickname given by the Apostles.

There are two things we need to note over the issue of the nickname: the nature of nicknames and meaning of the nickname. For Africans nicknames are not strange. Nicknames, for example, are very popular because of some cultural practices amongst Yoruba people. Traditionally, a newly wedded woman is not supposed to call the children she meets in the husband's family by name, and thus, the practice is to coin nicknames for them. In such cases, they come up with nicknames that are suitable for the children using physical qualities or some other characteristics. This example shows that by nature, nicknames are descriptive. With this being true, the nickname must give us an insight into Barnabas' character.

The name B $\alpha \rho v \alpha \beta \tilde{\alpha} \varsigma$ may be a compound Aramaic name from two words: $\beta \alpha \rho$ and $v \alpha \beta \tilde{\alpha}$. Luke helped us to understand the name by translating it into Greek: viò $\pi \alpha \rho \alpha \kappa \lambda \eta ́ \sigma \varepsilon \omega \varsigma$. Whilst we might not have any problem with the word viòs (son) as it is straightforward, $\pi \alpha \rho \alpha \kappa \lambda \eta \dot{\sigma \varepsilon \omega \varsigma}$ is a little more enigmatic. It can be translated variously as exhortation, admonition, encouragement, consolation and solace (Thomas 1993). This explains the various rendering of the term in different versions. The word son, as used here, actually means one who is the embodiment of something; it is a figurative usage (Hahn 1993). Thus, for the disciples, Joseph was an encourager, a consoler and a comforter per excellence! Supporting this, Murphy (2010) opined:

$[B]$ arnabas's role certainly involved his encouraging, exhorting and comforting others. That this was attributed to him by the apostles speaks of how he was perceived by the church leaders and reveals their admiration for him. (p. 321)

In verse 37, Barnabas undertook another act of encouragement: he sold his land and donated the money to the church. In summary, the major characteristic of Barnabas as a leader, as stated here, is his ability to encourage others. He is a builder of men and not a destroyer of people as most contemporary leaders in the church and the society.

Another relevant point to this study is Barnabas' tribal affiliation. As Barnabas was a Levite, he performed routine tasks in the temple, especially, the supportive role of slaughtering sacrificial animals, guarding the temple forecourt or singing in the temple (Kollmann 2004:7). Being a Jew and a Levite, however, 'shows Barnabas held a certain status in the Jewish communities of the first century' (Branch 2007:298). 


\section{Barnabas and Paul - First encounter (Acts 9:26-27)}

In Acts 9:26-27, Luke makes use of indirect characterisation leaving the readers to decide on Barnabas' character. The first encounter between Barnabas and Paul is recorded here. As the early Christian movement was regarded illegal, it would be understandable that on return to Jerusalem after his conversion, Paul found it difficult to join the church. However, the kind of person Barnabas was, he took the initiative of bringing Paul to the apostles. The Greek construction here is very instructive: the use of $\delta \dot{\varepsilon}$ shows that Barnabas is the only exception to the shutting out of the new convert. The use of $\dot{\varepsilon} \pi \lambda \alpha \beta{ }^{\prime} \mu \varepsilon v o \varsigma$, an aorist middle participle derived from a compound verb ( $\dot{\varepsilon} \pi \dot{i}$ and $\lambda \alpha \dot{\alpha} \mu \alpha \nu \omega)$ which should be translated 'seized' and not 'took' as most translations did, ${ }^{1}$ suggests a decisive and purposive action. He grabbed Saul with the intention that no one would stop him from taking Saul to the apostles. Another interesting point is the use of $\delta \eta \gamma \eta \dot{\sigma} \sigma \tau$ o to describe Barnabas' discussion with the apostles over Paul's issue. Liddell, Scott and Jones (1940) translated $\delta \eta \gamma \eta ́ \sigma \alpha \tau o$ as 'set out in detail', whilst Louw and Nida (1989) translated it as 'to provide detailed information in a systematic manner'. If this is what Barnabas did, then we need to ask, how did he get the detailed information? ${ }^{2}$ This means that whilst other disciples were avoiding Paul out of fear, Barnabas moved closer to listen to him. He was a leader who gives room for change of behaviour. Murphy (2010) described Barnabas here as follows:

$[B]$ arnabas is portrayed in the narrative not only as an advocator for Saul but also as an intermediary between him and the people.... Barnabas used his relationship with the apostles to speak up for Saul. (p. 323)

As an encourager, Barnabas is the voice for the voiceless.

\section{Barnabas and the church of Antioch (Ac 11:19-24)}

In this passage, Luke changes to direct characterisation by revealing us what Barnabas did and also proffering the reason behind the actions. The event here marked the third time where Barnabas' name was mentioned: it was in connection with the Antioch Church. The story has it that the believers who fled Jerusalem on account of persecution that rose against the church took the gospel along with them, preaching everywhere they went only to the Jews. However, for the men of Cyprus and Cyrene, things took a new turn as they shared the gospel with the Greeks who were turning to the Lord. Being a new development, the word came to the leaders of the church at Jerusalem who decided to send Barnabas to Antioch, as what I term 'apostolic delegate' to oversee the commencement of the Gentile ministry at

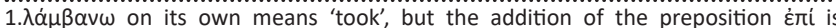
expected to alter its meaning, making 'sieze' most suitable (cf. Delling 1964

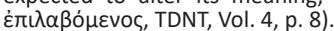

2.It is important to know that scholars like Wilson (2015) are arguing against this traditional understanding that it was Barnabas that was telling Saul's story to the Apostles.
Antioch. Barnabas' leadership characteristic shows forth in the actions he took on getting to Antioch.

Firstly, when he saw what the nameless and faceless men had performed, it was apparent that he bore no grudges and reprimands. On the contrary, he encouraged them to continue in the ministry. This is unlike ministers of today who likes to grab power and exercise authority over others. This again shows that Barnabas was, indeed, an encourager. According to Luke, this was possible because Barnabas possesses three sterling qualities:

1. He was a good man.

2. He was full of the Holy Spirit.

3. He was full of faith.

The construction of this passage is very important as the use of the subordinate conjunction ö $\tau$ (Ac 11:24) means the leadership characteristics displayed by Barnabas was made possible by his being full of faith and the Holy Spirit. Does this mean that contemporary leaders of the church quarrelling over power and position in the church are not full of faith and the Holy Spirit? Secondly, having seen the enormity of the work at Antioch, Barnabas remembered Paul, who had fled Jerusalem to Tarsus and decided to go and bring him up as he feels Paul would be useful to him in the ministry at the church of Antioch.

\section{Barnabas and Paul - Second encounter (Ac 11:25-26)}

In this passage, Luke again shifts to indirect characterisation. In one sentence (Ac 11:25-26a), he told us what Barnabas has carried out, and in the second sentence, (v. 26b) he told us the result of Barnabas' action. The second encounter between Barnabas and Paul occurs at Barnabas' instance: he decided to go and look for Paul in Tarsus to join him for the work at Antioch church. The Greek construction describing the process of searching for Paul is very instructive. According to Johannes, Louw and Nida (1989), $\dot{\alpha} \nu \alpha \zeta \eta \tau \tilde{\eta} \sigma \alpha 1$, an aorist active infinitive, implies 'to try to learn the location of something by searching for it' that is goaldirected search, and this explains why $\zeta \eta \tau \dot{\varepsilon} \omega \alpha$ was not used. It must be noted that this might subtly imply that Barnabas did not know Paul's location before going to search for him. In order to appreciate this, one needs to understand that Tarsus was a big city, the capital of the Roman province of Cilicia. It was famous for its university and a library that was said to have held over 200,000 volumes (Top 1915). Thus, Tarsus was a big commercial and cosmopolitan centre. Barnabas going to Tarsus to look for Paul can then be likened to someone going to Lagos or Johannesburg to look for someone without knowing the actual location. How many contemporary ministers can do this? Barnabas was a leader who fears no competition and sees no one as a threat. The result of Barnabas' selfless character was the quantitative and qualitative growth of the Antioch church. A truth is hidden here, which people seldom refer to: it was Barnabas who brought Paul to the ministry. I can assert 
that without Barnabas there would have never been Paul, yet Barnabas is usually forgotten.

\section{Barnabas and Paul - Leadership change (Ac 13: 13)}

After Barnabas brought Paul from Tarsus to join him in the ministry work at Antioch, it was discovered that when they are to be named together or listed along with others, Barnabas' name would be mentioned first. This is because in listing, Greeks usually start with the name of the most important person (Kucicki 2015). For example, if group members are to be listed, the leader's name would be mentioned first (Ac 11:26; 12:25; 13:1, 2 and 7). However, by the time the account gets to Acts 13:13, the narration changed and Paul's name was mentioned first, and surprisingly, Barnabas' name was not even mentioned at all. Can it be said that at this point, Paul took over the leadership of the missionary team from Barnabas? Confirming this leadership takeover, Stein (1974) stated:

According to Acts 11:25f. one year before the famine visit Barnabas brought Saul from Tarsus to assist him in the work at Antioch. From Acts it is evident that the leader of the team at this point was Barnabas, for when these two men are mentioned together the name of Barnabas is always placed first. It is only during the first missionary journey that Saul, who 'becomes' Paul, assumes the leadership role, for now we no longer read of Barnabas and Saul but of Paul and Barnabas. (p. 241)

The interesting thing to note about Barnabas was that he did not kick nor complained about this, and he stayed in the team and continued working with Paul. How many of our contemporary leaders can play the second fiddle where they had been the boss? How many contemporary leaders can allow the person they groomed into the ministry to take over the ministry from them and yet continue working with such a person?

Another intriguing point is the area Paul took over the leadership. According to the accounts recorded from Acts 13:1-12, they were at Paphos after they have left Salamis. Salamis and Paphos were leading ancient cities in Cyprus. If we go back to Acts 4, where Barnabas was first introduced, he was from Cyprus! Thus, it looks as if Paul took over the ministry leadership from Barnabas at Barnabas' home country. This, to us as Africans, smacks as affront. In most cases, one would be bitter and wish to fight to retain his leadership but not Barnabas. It is also disgusting that at this point Barnabas was just counted amongst the companions of Paul: no distinct personality was carved for him.

One of the final things to be noted is the last sentence of verse 13, which spoke about the return of John Mark to Jerusalem. Although this sentence seems out of place here, it is used in anticipation of the crisis between Barnabas and Paul. However, Luke was silent on the cause of John Mark's return. Various reasons have been cited for this, of which the following are the most common:
1. John Mark had grown up in a rich family and had not been used to the rigorous ministry life. As a result, he was homesick and returned to the rich life in Jerusalem.

2. The area of the next phase for the missionary trip after Paphos was a dangerous one, and that John Mark feared for his safety and others and he returned to Jerusalem

3. He was Barnabas' cousin, and he possibly did not like Paul taking over the ministry from Barnabas, and the only way he could protest was to jettison his membership in the team (Stenschke 2010).

Please note that no matter the plausibility of these reasons, it still must be taken that the Bible was silent on the reason.

\section{Barnabas and Paul - Discipleship training (Ac 15:36-40)}

In this passage, Luke employed indirect characterisation by telling us again what happened and expecting the readers to draw their conclusions. The final incidence that brought out the leadership trait in Barnabas was the encounter between him and Paul over John Mark as recorded above. When they were to embark on a return visit to the churches founded during their first missionary trip, Barnabas wanted then to take John Mark along with them; however, Paul objected on the basis of the fact that John Mark deserted them during the first journey and returned to Jerusalem. The disagreement was so sharp that the two parted ways. This incidence shows that unlike Paul, Barnabas was a leader who provides a second chance to people whilst grooming them to become leaders. He was willing to take John Mark with him, even though he deserted them during the first journey. As a leader, Barnabas was really an encourager and a builder of people from failures to achievers.

\section{Barnabas' character traits}

From the above analysis of the various passages recording events about Barnabas, the following picture emerges:

\section{Barnabas as an encourager}

The first thing readers are made to perceive about Barnabas is that he was an encourager. This was revealed through direct characterisation. He is one who helps people to maximise their potentials. He is one who would risk everything to ensure that all around him are successful and relevant. These are glaring in his relationship with Paul, as well as the nameless disciples who started the Antioch church. Those who have gone through rejection are the ones who can understand the frustration Paul would have been going through on his return to Jerusalem and his attempt to join the church. Barnabas moving close to him at this period would have encouraged him. His statement to the nameless disciples at Antioch also is a show of encouragement. As an apostolic delegate, a contemporary pastor or leader would have wanted to take full control and begin to introduce laws at curtailing the power of the nameless disciples. However, Barnabas encouraged them to continue with what they have been doing. 


\section{Barnabas as a relational bridge-builder}

Murphy's (2010) classification of Barnabas as a bridge builder would be adopted here. This was also depicted by his relationship with Paul. On this, Murphy (2010) says:

A key depiction of Barnabas in the narrative is as an intermediary, as a relational bridge builder. Paul's ministry was launched and influenced by his association with Barnabas. Barnabas was used by God to establish - not found- the church in Antioch and to help launch Paul. (p. 341)

The launching of Paul referred to by Murphey took place in two phases: the first was the introduction of Paul to the apostles and the disciples in Jerusalem. He was not only 'an advocate for Saul but also ... an intermediary between him and the people' (Murphy 2010:323). The second phase was his bringing Saul to Antioch to minister. In this narrative, Barnabas:

[I]ntroduced Saul to ministry in this city as he had done in Jerusalem. The relationship between Barnabas and the Antioch church and Saul became the bridge that linked Saul and the Antioch church. (Murphy 2010:326)

He is also non-discriminatory. Although a Jewish Levite as indicated earlier, his ability to work amongst fellow Jews and Gentiles shows that he was not discriminatory. The nature of leadership at Antioch church shows the multiracial nature of the city. This attitude is significant in multiracial and multiethnic settings, such as Nigeria and South Africa. In Nigeria, political leaders play the ethnic card to divide the people. Thus, we have a country that is at war with itself. Even the Nigerian church is also not spared from the evils of racial discrimination as sometimes offices are shared on the basis of kinship rather than merit.

\section{Barnabas as a team player}

Unlike many contemporary socio-religious leaders, Barnabas was a team player. He was a man who knows how to build a team that achieves. His ability to build teams is seen in his activities at Antioch. Firstly, on sensing the enormity of the work at Antioch, he went to Tarsus to fetch Paul to join him for the work at Antioch. Acts 13:1 testifies that the first multiminister church in the history of the church was built at Antioch under Barnabas' leadership.

\section{Barnabas is not power drunk}

Unlike many contemporary socio-religious leaders, Barnabas was not the person who holds tenaciously to power and do anything to retain that power. It cannot be doubted that Barnabas was the original leader of the team at the beginning of the ministry. In fact, the non-Christian characters mentioned in the account attest to that. As recorded in Acts 14:12, the people of Lystra identified Barnabas as Zeus (the head of the Greek pantheon) and Paul as Hermes (Zeus' spokesperson). However, when Paul took over the leadership and Barnabas became faceless ${ }^{3}$, he did not antagonise Paul, nor did he abandon the missionary trip. He participated in all tasks to the very end of the journey. He was a leader who is able to play the second fiddle where he had once called the shots.

\section{Barnabas is not avaricious}

Unlike most leaders today, Barnabas was a leader who is not avaricious, which is shown by his ability to sell his land, as recorded in Acts 4:36-37. If leaders who are not avaricious lead Nigeria, the socio-economic life of the country would be better by far. Rather than use the nation's wealth to develop the nation, Nigerian politicians and even church leaders would amass wealth at the expense of the people.

\section{The leadership gap in Nigeria vis-à- vis Barnabas' traits}

Leadership style, in any organisation, defines the character and output of such an organisation (Turknett \& Turnknett 2005). Schein (2010) noted that leaders are change agents, and for any transformative change to be realistic, leaders 'must unlearn something as well as learning something new' (p. 301). If the Nigerian society should be wholly transformed positively and effectively, then the Barnabas leadership model must be emulated. The 'old normal' leadership style, which breed evil, corrupt and unjust society, must be dropped (Anazodo, Igbokwe-Ibeto \& Nkah 2015). For example, the Nigerian political scene since independence has been ethnically biased. In fact, to date, political parties have been usually ethnically based (Ade-Ibijola 2016). This situation has created instability, tension and mistrust. As Ade-Ibijola (2016) stated, 'ethnic politics has put the Nigerian nation in a state of uncertainty' (p. 7). Thus, Nigeria needs political leaders who like Barnabas would be able to accommodate people from other ethnic groups and see them as part of the nation that they rightfully belong. The country requires leaders who would allow people from other racial groups to take leadership positions because they are qualified and have the technical expertise to do so.

Religious leaders are significant members in the society. They are saddled with the responsibility of ensuring a society void of immoralities and social vices. Unfortunately, many religious leaders in the contemporary society are materialistic and occupy political positions. Diara and Michael (2019) opined that many religious leaders see Christianity as a competitive market product to which market theory must be applied. Eventually, there is commercialisation of the Gospel. Hence, Nigerian religious leaders are not better than the political leaders. Similar to Barnabas, religious leaders must be ready to eschew greed, and lead the church members and the political class on the road of sacrificial and selfless service.

Barnabas was not only a bridge builder but also a team player, which the Nigerian society requires. Will there be a time when Nigerian leaders would be ready to make appointments based on abilities and technical knowhow 
rather than on political, religious or ethnic affinities. Two recent examples that are like a drop of water in the ocean include President Muhammadu Buhari's endorsement of Dr. Akinwumi Adesina, a card carrying member of the People's Democratic Party (PDP) of Nigeria, for the Presidency of the African Development Bank, despite the latter's membership of an oppositional party and his support also for Dr. Ngozi Okonjo-Iweala, also a member of the PDP, for the position of Director-General of the World Trade Organisation. Teamwork brings speed, growth and development just like it aided rapid spread of the gospel in the time of Barnabas and Paul.

A look at Nigeria today reveals a country torn apart ethnically, religiously and economically. There are calls for the disintegration of the nation, and some of these agitations are already assuming violent proportions (Eniayejuni \& Eikan 2015; Asaju, Arome \& Mukaila 2014). The country thus urgently needs a leader who would be able to heal old wounds, build up the country and lead her to the path of development. Only a leader like Barnabas can achieve this.

\section{Conclusion}

Many scholars have analysed the leadership problem in Nigeria. The similar conclusions show that the abysmal situation of Nigeria today is a direct consequence of leadership deficit. Most leaders are avaricious, egoistic, power drunk and visionless. As leadership determines the development of the nation, Nigerians must reject political and church leaders who do not have the leadership characteristics for the development of the nation. Leaders to be elected must, like Barnabas, be encouragers, bridge builders and team players who would harness the multiracial and multi-ethnic potentials of the country and build a virile nation. Leaders to be elected must be those tested and proven not to be avaricious or power drunk.

\section{Acknowledgements Competing interests}

The authors declare that they have no financial or personal relationships that may have inappropriately influenced them in writing this article.

\section{Authors' contributions}

O.A.A. conceived the idea of the study. He worked on the abstract, introduction, characterisation in Acts and the analysis of the Passages on Barnabas in the book of Acts. F.E.O. worked on the character traits of Barnabas based on the analysis of the Acts stories and the previous works carried out on Barnabas, the application to the Nigerian society and the conclusion.

\section{Ethical considerations}

This article followed all ethical standards for research without any direct contact with human or animal subjects.

\section{Funding information}

This research work received no specific grant from any funding agency in the public, commercial or not-for-profit sectors.

\section{Data availability}

Data sharing is not applicable to this article as no new data were created or analysed in this study.

\section{Disclaimer}

The views and opinions expressed in this article are those of the authors and do not necessarily reflect the official policy or position of any affiliated agency of the authors.

\section{References}

Ade-Ibijola, A.O., 2016, 'Ethnic politics in Nigeria: A post-independence reflection', Advances in Social Sciences Research Journal 3(4), 1-8.

Anazodo, R.O., Igbokwe-lbeto, C.J. \& Nkah, B.C., 2015, 'Leadreship, corruption and governance in Nigeria: Issues and categorical imperatives', African Research Review 9(2), 41-58. https://doi.org/10.4314/afrrev.v9i2.4

Asaju, K., Arome, S. \& Mukaila, I., 2014, 'Leadership crisis in Nigeria: The urgent need for moral education and value reorientation', Public Administration Research 3(1), 117-124. https://doi.org/10.5539/par.v3n1p117

Bennema, C., 2014, A theory of character in New Testament, Augsburg Fortress, Minneapolis, MN.

Branch, R.G., 2007, 'Barnabas: Early church leader and model of encouragement', In die Skriflig 41(2), 295-322. https://doi.org/10.4102/ids.v41i2.307

Cheng, L., 2011, The characterization of God in Acts: The indirect portrayal of an invisible character, Paternoster, Milton Keynes.

Darr, J.A., 1992, On character building: The reader and the rhetoric of characterization in Luke-Acts, John Knox, Louisville, KY.

Darr, J.A., 1993, 'Narrator as character: Mapping a reader-oriented approach to narration in Luke-Acts', Semeia 65, 47-48.

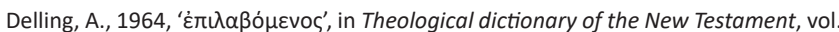
4, p. 8, Wm. B. Eerdmans, Grand Rapids, MI.

Diara, B. \& Mokwenye, M.E., 2019, 'A critical analysis of the social implications of gospel merchandising among Nigerian Christians today', Theological Studies 75(1), 1-6. https://doi.org/10.4102/hts.v75i1.5391

Eniayejuni, A. \& Evcan, N.S., 2015, 'Nigeria: Corruption arising from bad leadership', European Scientific Journal 11(13), 62-70.

Farelly, N., 2010, The disciples in the fourth gospel: A narrative analysis of their faith and understanding, Mohr Siebeck, Tübingen.

Gowler, D.B., 1991, Host, guest, enemy and friend: Portraits of the Pharisees in Luke and Acts, Peter Lang, New York, NY.

Hahn, F., 1993, 'viòc', in Exegetical dictionary of the New Testament, vol. 3, pp. 383-391, Wm. B. Eerdmans, Grand Rapids, MI.

Kollmann, B., 2004, Joseph Barnabas: His life and legacy, Liturgical Press, Collegeville, PA.

Kucicki, J., 2015, 'The conflict between Paul and Barnabas: Sitz im leben of Ac 15, 36-40', Journal of the Nanzan Academic Society Humanities and Natural Sciences 9, 87-98.

Liddell, H.G., Scott, R. \& Jones, H.S., 1940, A Greek-English lexicon, Clarendon Press, Oxford.

Louw, J.P. \& Nida, E.A., 1989, Greek-English Lexicon of the New Testament based on Semantic Domain, United Bible Societies, New York, NY.

Murphy, S.J., 2010, 'The role of Barnabas in the book of Acts', Bibliotheca Sacra 167, 319-341.

Rimmon-Kenan, S., 2002, Narrative fiction: Contemporary poetics, 2nd edn., Routledge, New York, NY.

Schein, E.H., 2010, Organizational culture and leadership, 4th edn., Jossey-Bass, San Francisco, CA.

Stein, R.H., 1974, 'The relationship of Gal 2:1-10 and Acts 15:1-35: Two neglected arguments', Journal of the Evangelical Theological Society 17(4), 239-242.

Shepherd, W.H., 1994, The narrative function of the holy spirit as a character in Luke-Acts, pp. 43-90, Scholars, Atlanta, GA.

Stenschke, C.W., 2010, 'When the second man takes the lead: Reflections on Joseph Barnabas and Paul of Tarsus and their relationship in the New Testament', Koers 75(3), 503-525. https://doi.org/10.4102/koers.v75i3.94

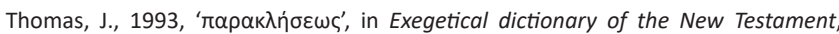
vol. 3, pp. 24-28, Wm. B. Eerdmans, Grand Rapids, MI. 
Thompson, R.P., 2006, Keeping the church in its place: The church as narrative character in Acts, T \& T Clark, New York, NY.

Top, M.N., 1915, 'Tarsus', in International standard Bible encyclopedia, viewed n.d., from https://accordance.bible/link/read/ISBE\#56319.
Turknett, R.L. \& Turknett, C.N. 2005, Decent people, decent company: How to lead with character at work and in life, Davies-Black Publishing, Mountain View, CA

Wilson, M., 2015, 'Barnabas or Saul: Who is describing Saul's Conversion in Acts 9:27?', Scriptura 114(1), 1-6. https://doi.org/10.7833/113-0-910 